\author{
Sólyom RÉKA \\ Károli Gáspár Református Egyetem \\ solyom.reka@kre.hu
}

\title{
EGYETEMISTÁK NYELVÉSZETI ISMERETEINEK MEGJELENÉSE A NEOLOGIZMUSOK TÉMAKÖRÉBEN
}

\section{Bevezetés}

A tanulmány egyetemi hallgatók nyelvészeti vonatkozású megjegyzéseit, reflexióit elemzi napjaink neologizmushasználatával kapcsolatban. A vizsgálat keretében különböző grammatikai felépítésű neologizmusok megértéséhez, befogadásához kapcsolódó adatközlői válaszok elemzésére kerül sor.

Az elemzés adatait adó felmérés beleilleszkedik a szerzőnek a témában végzett korábbi, empirikus kutatásaiba (1. pl. Sólyom 2014, 2018), amelyek során a neologizmusokhoz kapcsolódó befogadási, megértési folyamatok elemzésére került sor többek között egyetemi hallgatók körében.

Jelen elemzés egy 2018 tavaszán felvett kérdőíves felmérés vonatkozó eredményeire fókuszál. Ez a felmérés szerves folytatását képezi a szerző korábbi kutatásainak, amelyek során 2006 óta összesen 1487 adatközlő töltött ki kérdőíveket a nyelvi változási folyamatokkal (Keller 1990), illetve a neologizmushasználattal kapcsolatban.

A vizsgálódás célja annak tanulmányozása, hogy hogyan hatnak bizonyos nyelvészeti kurzusokon tanult ismeretek az egyetemi hallgatóknak a témában megadott reflexióinak, válaszainak szakszerűségére (például terminushasználatukra, egyes nyelvi jelenségek felismerésére stb.).

A hipotézis, a kérdőív, illetve az eredmények részletes bemutatása előtt a tanulmány röviden áttekinti a neologizmusok kérdésköréhez tartozó legfontosabb szakirodalmi megállapításokat, valamint közli azt a közlő-befogadó kommunikációs helyzetéből fakadó jellegzetességeket figyelembe vevő neologizmusdefiníciót, amelynek értelmében a tanulmány neologizmusnak tekint egyes nyelvi jelenségeket.

\section{Nyelvi változás és neologizmusok}

„A beszélők nem nyelvük fonológiai és grammatikai rendszerének megváltoztatására irányuló szándékkal hoznak létre újításokat. A beszélők azért indulnak ilyen irányba, mert meghatározott társadalmi céljaik vannak beszélőtársaikkal” - mutat rá Croft (2000: 59, fordítás tőlem).

Neologizmusok létrehozása esetében a cél gyakran nem pusztán az új kategóriák megnevezése, hanem a figyelem felkeltése, előtérbe helyezés, nyomatékosítás, 
a megjegyezhetőség elősegítése is (Benczes 2014: 110-111). Ez a törekvés gyakran párosul a játékossággal, illetve az ún. „trendiség”-gel is (vö. Lehrer 2003) - előbbi az írói, újságírói nyelvhasználat esetében gyakran megfigyelhető, utóbbi pedig a csoporthoz tartozás érzését is megerősítheti, hiszen a kommunikáció: olyan interaktív cselekvés a beszélö/író és a hallgató/olvasó között, amely „tágabb közegben a szociális kogníció része” (Tolcsvai Nagy 2012: 35, idézi Benczes 2014: 111-112).

Sok helyütt olvasható a neologizmusok témakörével kapcsolatban, hogy a fogalom definiálása nem egyszerű (l. pl. Minya 2003, 2011; Sólyom 2014). Jelen tanulmány a szerzőnek azt a funkcionális-kognitív keretben megadott korábbi neologizmusdefinícióját veszi alapul - némi változtatással -, amely a következőképpen foglalja össze a jelenség lényegét a közlő és a befogadó kommunikációs helyzetben betöltött helyzetét is figyelembe véve (Sólyom 2014: 19): a neologizmus „[...] olyan újszerű [...] nyelvi jelenség, melynek egy adott közlő és/vagy egy adott befogadó adott szituációban előzetes (vagy ilyen hiányában előzetesként értelmezett) tapasztalataihoz, ismereteihez és az ezekből fakadó elvárásaihoz viszonyítva újszerủ jelentést és/vagy újszerű stílust tulajdonít. E jelentés- és stílustulajdonítás dinamikus, a fenti változók függvényében skalárisan módosulhat egyazon nyelvhasználó esetében is.”

\section{A 2018. évi felmérésről}

A jelen dolgozat empirikus adatait adó vizsgálatra 2018 tavaszán került sor kérdőíves felmérés keretében. Mint fentebb olvasható, a felmérés a korábbi évek kutatásaihoz kapcsolódott. A 2018-ban lezajlott felmérésben a Károli Gáspár Református Egyetem Bölcsészet- és Társadalomtudományi Karának magyar BA-szakra, valamint osztatlan tanárképzésének 1-4. évfolyamára járó hallgatói vettek részt. A részvétel önkéntes volt, összesen 61 fö töltötte ki a kérdőívet.

A kitöltés során a kérdőívben összesen 12 neologizmussal kapcsolatban kellett válaszolniuk kérdésekre a hallgatóknak. Mind a 12 neologizmust szövegkörnyezetben, internetről, illetve kortárs szépirodalmi művekből származó mondatokban olvashatták az adatközlők.

\section{A vizsgálódás célja, hipotézise}

A vizsgálódás célja annak a tanulmányozása volt, hogy a kérdőívben kapott, egyetemi hallgatóktól származó válaszokban milyen módon jelennek meg azok az ismeretek, amelyekre nyelvészeti tanulmányaik során, nyelvészeti kurzusok keretében tettek szert. Feltételezhető ugyanis, hogy a bölcsészkaron tanuló hallgatók, akik kitöltötték a kérdőívet, korábbi tanulmányaiknak köszönhetően rendelkeznek olyan ismeretekkel (például ismernek vonatkozó terminusokat, felismernek nyelvi jelenségeket a kérdőív példamondataiban), amelyek megjelennek a kérdőív kérdéseire adott válaszaik megformálásában 
is. Ilyen módon a felmérés a neologizmusok felismerésén keresztül, illetve a jelentésükhöz és stílusukhoz kapcsolódó magyarázatokban arra kereste a választ, hogy hogyan hatnak bizonyos nyelvészeti kurzusokon tanult ismeretek a hallgatóknak a témában megadott reflexióinak, válaszainak szakszerűségére.

A hallgatóknak napjaink különböző grammatikai és szemantikai felépítésủ neologizmusaival kapcsolatban írásban kellett válaszolniuk néhány célzott kérdésre a felmérés során.

\section{A kérdőív felépítése}

A kérdőívben az alábbi neologizmusok (szavak) szerepeltek (betürendben, utánuk zárójelben a jelentés olvasható): adótraffipax ('a Nemzeti Adó- és Vámhivatal célzott adóellenőrzése, amelynek helyszínét elözetesen közzé is teszik a honlapjukon'), árfolyamrögzit ('rögzíti az árfolyamot'), beprágulás ('Prágához teljesen hasonlóvá válás'), bevállalhatatlanul ('úgy néz ki vagy viselkedik valaki, amit nem lehet vállalni'), bezzeg a nyolcvanasévekbenezisjobbvoltozik ('bosszúságában azt kiabálja, ismételgeti, hogy „bezzeg a nyolcvanas években ez is jobb volt!'”), buszsávozik ('jogszerütlenül, a közlekedési szabályokat megszegve személygépkocsival a buszok számára kijelölt forgalmi sávot használja'), fényfest ('fényfestéssel járó előadást tart'), ikertornyozik ('úgy néz ki vagy úgy viselkedik, hogy azáltal nagyon hasonlít egy híres emberre vagy [rajz]filmes karakterre'), király ('szuper, nagyszerü'), munkamegbeszél ('munkamegbeszélést tart'), „szertefelhöz' (Lackfi János) ('szétszáll, felhőszerűen szétterül a szélben'), „szinehagy” (Varró Dániel) ('elsápad').

Az adatközlőknek minden egyes neologizmus esetében az alábbi kérdésekre, instrukciókra kellett reagálniuk:

Mit jelent az idézetben aláhúzott szó? Adjon meg körülírást vagy szinonimákat a szóra!

Ön szerint milyen a megjelölt szó stílusa, hangulata?

Véleménye szerint könnyű megérteni az aláhúzott szót? Ha igen, miért? Ha nem, miért nem?

A kérdőív végén pedig szerepelt egy általános(nak szánt) témafelvetés; ezzel kapcsolatban kért a kérdőív állásfoglalást: Mi a véleménye: feltűnhetnek-e a fent aláhúzott új szavakhoz hasonló neologizmusok az oktatásban? Kell-e, lehet-e említést tenni róluk a magyarórán? Ha igen, miért és milyen témakörökhöz kapcsolódóan? Ha nem, miért nem? Röviden fejtse ki véleményét!

\section{A kérdőív neologizmusainak grammatikai felépítése és csoportosításuk a grammatikai felépítés alapján}

A kérdőívben szerepelő neologizmusok különböző szóalkotási módok segítségével jöttek létre. Ezek a következők: szóképzés, szóösszetétel, elvonás, szófajváltás, be igekötő kapcsolása a szótőhöz. Az alábbiakban ezeknek a szóalkotásmódoknak a rövid jellemzése 
(a Magyar grammatika című egyetemi tankönyv alapján), illetve a kérdőív neologizmusainak az egyes szóalkotásmódok közé sorolása következik.

\subsection{Szóképzés}

„A szóképzés a szóalkotásnak az a módja, amikor a szótőhöz egy képző hozzájárulásával új szó jön létre" (Keszler 2000: 307).

Szóképzéssel keletkezett neologizmusok a kérdőívben: beprágulás, bevállalhatatlanul, bezzeg a nyolcvanasévekbenezisjobbvoltozik, buszsávozik, ikertornyozik, szertefelhöz.

\subsection{Szóösszetétel}

„A szóösszetétel (compositio) az egyik leggyakoribb szóalkotásmódunk, mellyel szinte korlátlan mértékben növelhetjük szótári szavaink számát. A szóösszetétel során két vagy több szóalak összekapcsolásával hozunk létre új lexémát, melyet alaki felépítése alapján összetett szónak (compositum) nevezünk [...]” (Lengyel 2000b: 321).

Szóösszetétellel keletkezett neologizmus a kérdőívben: adótraffipax. (Itt meg kell említeni, hogy több, szóképzéssel, illetve elvonással keletkezett példa esetében is összetett szó volt a kiinduló állapot, például: buszsávozik, ikertornyozik; fényfest, munkamegbeszél.)

\subsection{Elvonás}

„Elvonásnak nevezzük azt a jelenséget, amikor egy egyszerű szóról leválasztunk egy meglévő vagy vélt morfémát - általában képzőt vagy összetételi elő-, utótagot -, a maradék morfémát vagy morfémacsoportot pedig teljes szóként kezdjük használni” (Lengyel 2000c: 340).

Elvonással létrejött neologizmusok a kérdőívben: árfolyamrögzít, fényfest, munkamegbeszél, szinehagy.

\subsection{Szófajváltás}

„A szófajváltás terminus többféle és sokirányú nyelvi folyamatot takar. [...] A szavak lexikai jelentését érintő szófaji változást lexikai szófajváltásnak nevezzük. A lexikai szófajváltás során megváltozik a szavak jelentése, legtöbbször toldalékolhatósága és bővíthetősége is. [...] A szófajváltás ilyenkor lehet teljes, tudniillik az eredeti szófaj kivész, eltűnik; de kialakulhat az úgynevezett kettős szófajúság is” (Lengyel 2000a: 78).

Szófajváltással létrejött neologizmus a kérdőívben: király.

\subsection{Vonatkozó válaszok: stílus}

A vizsgálódás első része a felsorolt neologizmusok stílusával kapcsolatos adatközlői válaszokra fókuszál, és ezek közül a vonatkozó válaszok közül mutat be néhány jellemző példát. Általánosságban elmondható, hogy a stílusra vonatkozó kérdésekre adott válaszok esetében két, egymással ellentétes adatközlői attitűd mutatkozott meg.

Az első típusba tartozó adatközlői válaszok esetében egyértelműen tapasztalható a nyelvészeti tanulmányok hatása. (A kérdés, amelyre válaszolnia kellett az adatközlőknek, 
a következő volt: „Ön szerint milyen az aláhúzott szó hangulata, stílusa?”) A hallgatók vonatkozó válaszaiban elsősorban a stilisztikai és a kommunikációs kurzusok terminusai jelentek meg, úgymint például reflektálás beszélő és hallgató viszonyára vagy utalás a stílus szociokulturális rétegzettségére (Tolcsvai Nagy 2012). A következőkben néhány ilyen, a stílushoz kapcsolódó releváns válasz felsorolása olvasható. (Jelen tanulmány egyik kérdéskör esetében sem közli az összes, vonatkozó adatközlői választ, hanem néhány „prototipikus”-nak tekinthető vagy több adatközlö által is megadott vélekedést foglal össze.)

A vizsgált neologizmusok stílusához kapcsolódó, az adatközlők nyelvészeti ismereteit tükröző vonatkozó válaszok (példák): köznyelvi, hivatalos, informális, ironikus, laza, modern, pejoratív, szaknyelvi, szleng, tudományos.

Mint látható, a fenti felsorolásba tartozó kategóriák elsősorban a nyelv normatív és társadalmi rétegzettségét (vö. Kiss 2002: 74-78), valamint stilisztikai szempontból a kommunikációs helyzettől függő szociokulturális rétegzettséget (vö. Tolcsvai Nagy 2012) veszik alapul. Az említett felosztásokat, megközelítéseket tartalmazó nyelvészeti szakirodalmat a hallgatók szociolingvisztikai, illetve stilisztikai tanulmányaik (előadások, szemináriumok) során tanulják, e tanulmányoknak köszönhetően jelenhettek meg a kérdőív szavaira történő reflexióikban a fenti terminusok.

\subsection{Egy váratlan eredmény: értékítéletek (néhány példa)}

Kisebb mértékben, kevesebb esetben ugyan, de megfigyelhető volt a vonatkozó válaszokban egy másik tendencia is. A stílussal kapcsolatos reflexiók esetében ugyanis a fent említett kérdésnél (kb. a válaszok 15-20\%-ában) feltűntek értékítéletet tükröző megjegyzések is. Ezekben a válaszokban az adatközlők szubjektív véleményüket, általában negatív kritikájukat fejezték ki a kérdőív neologizmusaival kapcsolatban. A következőkben ilyen válaszokra olvasható néhány példa (a megjegyzés után a jellemzett neologizmussal): rossz hangulata van; béna (adótraffipax); nevetséges; erőltetett (beprágul); fura; barátságtalan (bevállalhatatlanul); ellenszenves; kompromittáló (bezzeg a nyolcvanasévekebenezisjobbvolt-ozik); esetlen, fellengző (sic!) (fényfest); irodai, sietős (sic!) (munkamegbeszél).

\subsection{Vonatkozó válaszok: grammatikai, szemantikai jellemzők}

A kérdőívnek ezek a kérdései a vizsgált neologizmusok grammatikai és/vagy szemantikai jellemzőihez kapcsolódtak. (A kérdőívben ehhez a témakörhöz az alábbi kérdések kapcsolódtak: „Véleménye szerint könnyü megérteni az aláhúzott szót? Ha igen, miért? Ha nem, miért nem?”)

Általános tapasztalatként megfogalmazható, hogy nem volt releváns különbség a kapott válaszok „helytállóságában” (pontosságában, korrekt terminushasználatában) a tekintetben, hogy hányadik évfolyamra, illetve a tekintetben, hogy valamilyen osztatlan tanári szakra vagy magyar BA-ra jár a választ adó adatközlő: mindkét típusú képzés képviselői esetében kb. azonos arányban fordult elő pontos megnevezés (például 
a grammatikai szerkezet vagy a szóalkotásmód tekintetében), illetve tévedés (amikor például az elvonást szóképzésként definiálta az adatközlő).

Megfigyelhető volt még továbbá az is, hogy az adatközlők válaszaikban elsősorban a neologizmusok grammatikai felépítésére reflektáltak, és a megértési/meg nem értési folyamatokat ezekkel a grammatikai jellemzőkkel hozták kapcsolatba. A vizsgált neologizmusok szemantikai felépítésével (például a be igekötő jelentésmódosító szerepével vagy a képzés-szóelvonás metonimikusságával) kapcsolatban gyakorlatilag nem is adtak meg releváns választ az adatközlők.

Az alábbiakban néhány példa bemutatása következik a fentiekre (releváns - nem releváns meghatározások). A válasz idézése után zárójelben olvasható egyrészt a neologizmus, amellyel kapcsolatban az idézett választ adta az adatközlö, másrészt az adatközlő szakja és évfolyama.

A kérdőív neologizmusaival kapcsolatban relevánsnak tekinthető, pontos nyelvészeti terminusokat és meghatározásokat tartalmazó válaszokra következik néhány példa az alábbiakban: „Igen, a szóösszetétel tagjai segítik a megértést” (adótraffipax, osztatlan magyar-angol tanári szak, 2. évf.); „Igen; anyanyelvi beszélő egyszerűen felismeri az ilyen szóképzést” (beprágulás, osztatlan magyar-angol tanári szak, 3. évf.); „Igét képeznek az érthető kifejezésből” (bezzeg a nyolcvanasévekbenezisjobbvoltozik, magyar BA, 1. évf.); „Igen, mert ismerjük a képzett fönevet, amiből elvontuk a képzőt” (munkamegbeszél, magyar BA, 2. évf.); „Igen, mert csak szóvégi elvonás történt” (munkamegbeszél, osztatlan magyar-angol tanári szak, 2. évf.).

Nem releváns, pontatlan vagy téves meghatározások (például szóalkotásmódok összetévesztése, nem releváns nyelvészeti terminusok említése, homályos, nem releváns megfogalmazásmód) is olvashatók a válaszok között a grammatikai és a szemantikai jellemzők tekintetében (zárójelben ismét a kérdéses neologizmus és az adatközlő szakja, évfolyama olvasható), úgymint (példák): „Nem, mert a két $f$ betü és az $x$ nehezíti [a megértést]” (adótraffipax, magyar BA, 2. évf.); „Könnyü, kicsit szokatlan, de egyre gyakoribb szóképzés” (árfolyamrögzit, magyar BA, 2. évf.); „Könnyü, a fönév igévé válása egyértelmüen mutatja, hogy valamilyen hasonulási folyamatról van szó" (beprágul, magyar BA, 3. évf.); „Igen, mert értem a szó összes részét és az összetételt is” (bevállalhatatlanul, osztatlan magyar-angol tanári szak, 2. évf.); „Igen, mert a szó megjelöli a kontextust” (buszsávo$z i k$, osztatlan magyar-angol tanári szak, 2. évf.).

\subsection{Egy váratlan eredmény: értékítéletek, nyelvi ideológiák (néhány példa)}

Kissé meglepő volt, hogy a kérdőívnek a megértésre, befogadási folyamatokra vonatkozó részében, tehát a szemantikai és a grammatikai felépítést célzó kérdések esetében adott válaszokban is megjelentek olyan - tipikusan negatív - értékítéleteket, nyelvi ideológiákat tükröző válaszok, amelyek a vizsgált neologizmusok felépítéséhez, be- és elfogadásához kapcsolódtak. Ilyenek voltak például a következők: „csúnya magyar”, „magyartalan, ezt nem szeretem” (az elvonásról, hasonló példának hozza a szakdolgoz szót), „helytelennek 
tűnik”, „hibásnak érzem”, „hát, igekötő nem kellene elé, de értheto”” (be igekötős neologizmusokról), „itt sem jó az igeköto”” (be igekötős neologizmusról), „hát, szerintem alkalmatlan szónak” (sic!) (képzett szóról), „nem magyaros”, „rossz, erőltetett”.

\section{Neologizmusok a (köz)oktatásban}

A kérdőív végén a hallgatóknak lehetőségük nyílt válaszolni olyan nyitott kérdésekre is, amelyek a neologizmusoknak az oktatásban való megjelenéséhez, tárgyalásához kapcsolódtak. A vonatkozó kérdések a következők voltak: „Mi a véleménye: feltűnhetnek-e a fent aláhúzott új szavakhoz hasonló neologizmusok az oktatásban? Kell-e, lehet-e említést tenni róluk a magyarórán? Ha igen, miért és milyen témakörökhöz kapcsolódóan? Ha nem, miért nem? Röviden fejtse ki véleményét!"

A téma - a neologizmusok megjelenése a (köz)oktatásban - megjelenik a Nemzeti Alaptantervben is, röviden összefoglalva a következőképpen (NAT 2012: 34): 7-8. osztályban a „példák [...] alapján a nyelvi állandóság és változás megfigyelése a mai állapottal való összevetés során, elsősorban a szókincsben és a tanult nyelvtani jelenségek szintjén”, míg 9-12. osztályban a „napjaink nyelvi változásainak felismerése” témakörrel kapcsolatban.

A 2018 tavaszán felvett kérdőív vonatkozó eredményeiről elmondható, hogy az adatközlők nagy többsége $(75,41 \%$-a) válasza alapján fontosnak tartja a neologizmusok és a nyelvi változás témakörének tárgyalását az oktatásban. 61 kérdőív közül ugyan 13 esetben $(21,31 \%)$ nem válaszoltak a hallgatók ezekre a kérdésekre, de az mindössze 2 esetben $(3,28 \%)$ fordult elö, hogy úgy nyilatkozott az adatközlö, hogy véleménye szerint nem kell beszélni a témáról az oktatás során.

Összehasonlításképpen: egy 2015-ben bölcsészhallgatók körében végzett hasonló vizsgálódás során a kérdőívnek a hasonlóképpen a neologizmusoknak a (köz)oktatásban való feltűnésével, tárgyalásával kapcsolatos kérdésére alapvetően háromféle vélemény rajzolódott ki a vonatkozó válaszokból: 1) kell, hasznos beszélni a neologizmusokról, hiszen nap mint nap feltünnek a diákok nyelvhasználatában is; 2) kell tárgyalni a neologizmusokat az oktatásban, de fontos meghatározni, milyen kommunikációs szituációban használatosak; 3) nem tanácsos beszélni a neologizmusokról a magyar nyelvi órákon, mivel azok között sok „hibás” és „helytelen” is található - ezek között elsősorban sajtó- és reklámnyelvi, illetve internetes társalgásra jellemző példákat soroltak az adatközlők (Sólyom 2018: 204-206).

A 2018-ban erre a kérdésre kapott válaszok tekintetében mindenképpen pozitív eredmény, hogy az adatközlőknek az említett 75,41\%-a úgy vélekedett: van helye, méghozzá fontos helye a neologizmusok és a nyelvi változás tárgyalásának a (köz)oktatásban.

Az alábbiakban az ő válaszaik közül következik néhány; kifejezetten olyan válaszok ezek, amelyekben - a jelen vizsgálódás céljainak megfelelően - megjelenik a releváns szaknyelvi terminushasználat (az erre vonatkozó utalásokat, megjegyzéseket a szerző által kiemelve közli a következő felsorolás): 
„Persze hogy kell, a fiatalok is folyton alkotnak új szavakat, érdeklik őket az új kifejezések - és fontos, hogy érezzék, ők is alakítják a nyelvet, mert ők is beszélők. A neologizmus nem bün (sic!). Irodalom- és nyelvtanórán egyaránt lehet vele foglalkozni."

„Fontos említést tenni róluk, hiszen jelentős, egyre szélesebb körökben érvényesülő nyelvi változások, amik a nyelv egészét befolyásolják előbb-utóbb.”

„A nyelvújitás kapcsán is felmerül a neologizmus témaköre, azonban a mai magyar nyelvállapothoz kapcsolódóan is beszélni kell a témáról. A nyelv természetes változásának jelei a neologizmusok, nem értelmezhetők a nyelv romlásaként.”

„Mindenképpen beszélni kellene róluk a tanórákon, mert sok diák nem tudja, hogy az élet mely színterein milyen szóhasználatot illő használni [...].”

„Szerintem fontos, hogy a magyarórákon legyen szó a neologizmusokról is, mivel a tanulók, hallgatók használják és értik ezeket, s talán ezeken keresztül könnyebben megértik a szóképzést, szószerkezeteket, elvonást stb."

\section{9. Összegzés}

A 2018 tavaszán bölcsészhallgatók körében felvett kérdőív kérdéseire kapott válaszok nemcsak a jelentés- és stílustulajdonítás folyamatára világítottak rá a neologizmusok témakörével kapcsolatban, hanem a hallgatóknak a nyelvészeti ismeretekben való jártasságát, valamint az adatközlőknek azt a véleményét is tükrözték, hogy szerintük milyen szerepet célszerủ szánni a jelenségnek az oktatási folyamatban.

A vizsgálódás hipotézis beigazolódott: markánsan megjelentek ugyanis a magyar szakon tanultak a vonatkozó válaszokban mindkét típusú képzésre (BA, osztatlan tanári szak) járó adatközlők esetében. Jelentős különbség ugyanakkor nem volt kimutatható a két csoport vonatkozó válaszai között. A várakozásoknak megfelelően kisebb-nagyobb pontatlanságok, tárgyi tévedések előfordultak néhány esetben egy-egy nyelvi jelenség (például szóalkotásmódok) meghatározása esetében.

Váratlan eredményként tüntek fel ugyanakkor néhány esetben a neologizmusokkal, illetve a nyelvi változási folyamatokkal kapcsolatban megfogalmazott értékítéletek és nyelvi ideológiák. Ezeknek némiképpen ellentmond, hogy a neologizmusok oktatásban való megjelenését az adatközlőknek kicsivel több mint háromnegyede fontos, hasznos és feltétlenül tárgyalandó témának tartja.

\section{Források}

Lackfi János 2000. Öt seb. Versek. Budapest: Belvárosi Könyvkiadó. 89. Varró Dániel 1999. Bögre azúr. Versek. Budapest: Magvető. 14. 


\section{Irodalom}

Benczes Réka 2014. Ami rímel, az stimmel: Az alliteráció és a rím szerepe a neologizmusokban. In: Ladányi Mária - Vladár Zsuzsa - Hrenek Éva (szerk.): Nyelv, társadalom, kultúra: interkulturális és multikulturális perspektivák I-II.: a XXIII. Magyar Alkalmazott Nyelvészeti Kongresszus (ELTE BTK Budapest, 2013. március 26-28.) elöadásaiból készült tanulmánykötet. Budapest: MANYE - Tinta Könyvkiadó. 109-114.

Croft, William 2000. Explaining Language Change. An Evolutionary Approach. Harlow, New York: Longman.

Keller, Rudi 1990. Sprachwandel: von der Unsichtbaren Hand in der Sprache. Tübingen: Francke.

Keszler Borbála 2000. A szóképzés. In: Keszler Borbála (szerk.): Magyar grammatika. Budapest: Nemzeti Tankönyvkiadó. 307-320.

Kiss Jenő 2002. Társadalom és nyelvhasználat. Szociolingvisztikai alapfogalmak. Budapest: Nemzeti Tankönyvkiadó.

Lehrer, Adrienne 2003. Understanding Trendy Neologisms. Rivista di Linguistica 15/2: 369-382.

Lengyel Klára 2000a. A szófajváltás. In: Keszler Borbála (szerk.): Magyar grammatika. Budapest: Nemzeti Tankönyvkiadó. 78-79.

Lengyel Klára 2000b. A szóösszetétel. In: Keszler Borbála (szerk.): Magyar grammatika. Budapest: Nemzeti Tankönyvkiadó. 321-336.

Lengyel Klára 2000c. Az elvonás. In: Keszler Borbála (szerk.): Magyar grammatika. Budapest: Nemzeti Tankönyvkiadó. 340-341.

Minya Károly 2003. Mai magyar nyelvújitás - szókészletünk módosulása a neologizmusok tükrében a rendszerváltozástól az ezredfordulóig. Budapest: Tinta Könyvkiadó.

Minya Károly 2011. Változó szókincsünk. A neologizmusok több szempontú vizsgálata. Budapest: Tinta Könyvkiadó.

NAT 2012 = 110/2012. (VI. 4.) Korm. rendelet a Nemzeti alaptanterv kiadásáról, bevezetéséről és alkalmazásáról. Magyar Közlöny 66: 10635-10848. http://ofi.hu/sites/ default/files/attachments/mk_nat_20121.pdf (2019.03.02.)

Sólyom Réka 2014. A mai magyar neologizmusok szemantikája. Nyelvtudományi Értekezések 165. Budapest: Akadémiai Kiadó.

Sólyom Réka 2018. A kérdőíves felmérések szerepe kognitív szemantikai és stilisztikai elemzésekben. In: Domonkosi Ágnes - Simon Gábor (szerk.): Nyelv, poétika, kognició. Elmélet és módszer a poétikai kutatásban. Eger: Líceum Kiadó. 197-209.

Tolcsvai Nagy Gábor 2012. A stílus szociokulturális tényezőinek kognitív nyelvészeti megalapozása. In: Tátrai Szilárd - Tolcsvai Nagy Gábor (szerk.): A stílus szociokulturális tényezöi. Kognitiv stilisztikai tanulmányok. Budapest: ELTE. 19-49. 